\title{
A new method for quantification of total polyphenol content in medicinal plants based on the reduction of Fe(III)/1,10-phenanthroline complexes
}

\author{
Mônica Gabriela do Santo ${ }^{1}$, Cecilia Veronica Nunez ${ }^{2}$, Horacio Dorigan Moya ${ }^{{ }^{*}}$ \\ ${ }^{1}$ Faculdade de Medicina da Fundação do ABC, CEPES (Centro de Estudos, Pesquisa, Prevenção e Tratamento em Saúde), Santo \\ André, Brazil \\ ${ }^{2}$ Laboratório de Bioprospecção e Biotecnologia, COTI (Coordenação de Tecnologia e Inovação), INPA (Instituto Nacional de \\ Pesquisas da Amazônia), Manaus, Brazil \\ Email: "horacio.moya@fmabc.br
}

Received 20 September 2013; revised 28 October 2013; accepted 12 November 2013

Copyright (C) 2013 Mônica Gabriela do Santo et al. This is an open access article distributed under the Creative Commons Attribution License, which permits unrestricted use, distribution, and reproduction in any medium, provided the original work is properly cited.

\begin{abstract}
This paper proposes an alternative analytical spectrophotometric method for the total polyphenol quantification in the aqueous extract of plants. When these extracts are added to solutions of $\mathrm{Fe}(\mathrm{III})$, in presence of 1,10-phenanthroline, the absorbance values at 551 nm $\left(\mathbf{A}_{511 \mathrm{~nm}}\right)$ due to the $\mathrm{Fe}(\mathrm{phen})_{3}^{2+}$ complexes formed are proportional to the total polyphenol concentration expressed as pyrogallic acid (PA). A typical calibration graph of $A_{511 \mathrm{~nm}}$ values vs. $P A$ is linear from 0.16 to $0.64 \mathrm{mg} \mathrm{L}^{-1}(r=0.994, n=6)$ with a limit of detection $0.041 \mathrm{mg} \mathrm{L}^{-1}$. The results of the polyphenol content of the aqueous extracts of twenty medicinal Brazilian plants obtained with the proposed method were compared with values using the FolinCiocalteu reagent. A paired t-test revealed no statistically significant difference for the species analyzed. The total antioxidant capacity of the same twenty extracts was determined based on the scavenging of stable radical DPPH.
\end{abstract}

Keywords: Polyphenols; Medicinal Brazilian Plants; 1,10-Phenanthroline; Iron (III); Antioxidant Activity

\section{INTRODUCTION}

Since about 1930 studies have demonstrated that among all the metal ions which are complex by the uncharged ligand 1,10-phenantroline (1,10-phen), the iron(II) complexes formed, $\mathrm{Fe}(\mathrm{phen})_{3}^{2+}$, is the species which produces more intense color [1]. This orange-red ferrous chelate is very stable $\left(\log \beta_{3}=21\right)$ [2] and has been used for the determination of iron ion in various types of

${ }^{*}$ Corresponding author. samples after reduction of total iron to Fe(II) by the addition of a suitable reducing agent. For this purpose, several reducing compounds have been used like hydroxylamine hydrochloride, hydrazine, sodium sulphite (or hydrosulphite), stannous chloride, sodium formate, formaldehyde, sodium hypophosphite, ascorbic acid, hydroquinone and tannic acid [1].

Consequently, any reducing agent capable of converting $\mathrm{Fe}(\mathrm{III})$ to $\mathrm{Fe}(\mathrm{II})$ in a medium containing 1,10-phen could be indirectly determined by measuring the amount of $\mathrm{Fe}(\mathrm{phen})_{3}^{2+}$ complexes formed. In spite of that, there are not many analytical methodologies available in literature for the quantification of reducing compounds using the $\mathrm{Fe}(\mathrm{phen})_{3}^{2+}$ complexes. Some examples are presented in Table 1.

Ascorbic acid is the compound that has been more indirectly determined in complex matrices such as fruit juices, soft drinks and teas [3], fruits and vegetables [4], beers and soft drinks [5] and tablets [6]. The total concentration of tannins (or tannic acid) in teas and beers [7], hop [8] and tannery wastewater [9] was also determined. The majority of analytical methods available in the literature for these two analytes can probably be attributed to the fact that both are strong reducing agents in aqueous solution, which makes the procedure more easily performed.

$\alpha$-Tocopherol, an oil-soluble vitamin, required the use of surfactants for its determination in oil facial [10] and milk powder [11]. Hydrogen sulfide was quantified in various samples (wastewater, lake water, coconut, sugarcane juice and egg) in acidic media waiting some minutes for the total reduction of $\mathrm{Fe}$ (III) [12].

Formaldehyde was determined in wastewater after reaction with an excess of a stronger reducing agent, 
Table 1. Selected spectrophotometric analytical methods for indirect determination of reducing compounds exploiting the $\mathrm{Fe}(\text { phen })_{3}^{2+}$ complex formation.

\begin{tabular}{|c|c|c|c|c|}
\hline $\begin{array}{c}\mathbf{L R} \\
(\mathrm{g} / \mathrm{mL})\end{array}$ & $\underset{(g / m L)}{\mathbf{L D}}$ & Analyte & Remarks & Ref. \\
\hline $0-8$ & NA & Ascorbic acid & $\begin{array}{l}\text { Detn. of AA in canned fruit juices, cordials, tea and soft drinks. Background correction } \\
\text { was needed and interference was noted in presence of TA, PA and sulphite. }\end{array}$ & 3 \\
\hline $0-2.8$ & NA & Ascorbic acid & $\begin{array}{l}\text { Detn. of AA in fruits and vegetables based on the formation of the ionic pair between } \\
\mathrm{Fe}(\mathrm{phen})_{3}{ }^{2+} \text { and BPR in the presence of CTMAB (pH 6.0, HOAc-NaOAc). RSD } 1.1-3.7 \% \text {. }\end{array}$ & 4 \\
\hline $\begin{array}{l}5-80 \\
1-80\end{array}$ & $\begin{array}{l}2.7 \\
0.5\end{array}$ & $\begin{array}{l}\text { Ascorbic acid (NPC) } \\
\text { Ascorbic acid (PC) }\end{array}$ & $\begin{array}{l}\text { Two spectrophotometric FIA methods (NPHC and PHC) for the detn. of AA in soft } \\
\text { drinks and beers. The NPHC is based on the reduction of Fe(III) forming the Fe(phen })_{3}{ }^{2+} \\
\text { complexes. The PHC uses the irradn. with visible light to achieve higher sensitivities. NFC } \\
\text { has RSD 1.6\% }(\mathrm{n}=11) \text { and } 60 \text { samples }^{-1} \text {. PC has } 1.0 \%(\mathrm{n}=11) \text { and } 40 \text { samples }^{-1} \text {. }\end{array}$ & 5 \\
\hline $\begin{array}{l}0.50-4.00 \\
1.00-8.00\end{array}$ & $\begin{array}{l}\text { NA } \\
\text { NA }\end{array}$ & $\begin{array}{l}\text { Ascorbic acid } \\
\text { L-Cysteine }\end{array}$ & $\begin{array}{l}\text { Simultaneous detn. of AA and L-Cys in tablet samples using the HPSAM based on the } \\
\text { difference of the reaction rates between AA and L-Cys with Fe(III). RSD for } 3.0 \mathrm{ppm} \\
\qquad(\mathrm{n}=6) \text { for AA }(2.3 \%) \text { and L-Cys }(2.7 \%) .\end{array}$ & 6 \\
\hline $0-30$ & NA & Tannins & $\begin{array}{l}\text { FIA method for the detn. of tannins in tea and beer. GA as std. RSD for } 10 \mathrm{mg} \mathrm{L}^{-1} \mathrm{GA} \\
\qquad 0.7 \%(\mathrm{n}=10) ; 60 \text { samples }^{-1}\end{array}$ & 7 \\
\hline $0.10-5.0$ & 0.05 & Tannins & Detn. of tannins in tannery wastewater; RSD is $0.492 \%$. & 8 \\
\hline $0-300$ & 0.84 & Tannic acid & $\begin{array}{l}\text { FIA kinetic method for detn. of TA in hops. TA is injected into a stream of Fe(III) and } \\
\text { mixed with 1,10-phen }\left(0.03 \mathrm{~mol} \mathrm{~L}^{-1} \mathrm{H}_{2} \mathrm{SO}_{4} \text { medium). } 71 \text { samples } \mathrm{h}^{-1} \text { (RSD } 1.1 \%\right) \text {. }\end{array}$ & 9 \\
\hline $5.17-400$ & 0.86 & $\alpha$-Tocopherol & $\begin{array}{l}\text { FIA method for the detn. Of -tocopherol in facial oil using SDS oil in water micro emulsion } \\
\left.\text { as single-phase extraction. } 60 \text { samples }^{-1} \text { (RSD } 0.03 \%\right) \text {. }\end{array}$ & 10 \\
\hline $0.21-43$ & 0.05 & $\alpha$-Tocopherol & FIA method for detn. of $\alpha$-tocopherol in milk powder. 30 samples $^{-1}(\operatorname{RSD} 1.2 \%, n=4)$. & 11 \\
\hline $035-1.40$ & NA & Hydrogen sulfide & Detn. of $\mathrm{H}_{2} \mathrm{~S}$ in lake water, industrial effluents, tender coconut, sugarcane juice and egg. & 12 \\
\hline $0.25-1.0$ & 0.02 & Formaldehyde & $\begin{array}{l}\text { FIA method for detn. of } \mathrm{HCHO} \text { in wastewater based on the conndensation of } \mathrm{HCHO} \text { with } \\
\left(\mathrm{NH}_{2} \mathrm{OH}\right)_{2} \cdot \mathrm{H}_{2} \mathrm{SO}_{4} \text { producing formaldoxime. Residual }\left(\mathrm{NH}_{2} \mathrm{OH}\right)_{2} \cdot \mathrm{H}_{2} \mathrm{SO}_{4} \text { reduces } \mathrm{Fe}(\mathrm{III}) \text { in } \\
\text { presence of } 1,10 \text {-phen. RSD was } 2.03 \% \text { for } 0.25 \mathrm{mg} \mathrm{L}-1 .(\mathrm{n}=4) .15 \text { samples } \mathrm{h}^{-1} \text {. }\end{array}$ & 13 \\
\hline $0.18-180$ & 0.09 & Glucose & $\begin{array}{l}\text { FIA method for detn. of glucose in wine and human blood plasma. The method is based on } \\
\text { passing a glucose solution containing Q through a column immobilized with glucose } \\
\text { oxidase. In the flow system Q is reduced to HQ glucose and the HQ formed reduces Fe(III) } \\
\text { in a } 1,10 \text {-phen medium. } 24 \text { samples } \mathrm{h}^{-1} \text {. RSD was } 0.78 \%(\mathrm{n}=5) \text { for } 5 \mathrm{M} \text { glucose. }\end{array}$ & 14 \\
\hline $1-120$ & 0.5 & Citric acid & $\begin{array}{l}\text { FIA method for detn. of CA in beverages based on the photoreduction of } \mathrm{Fe}^{3+} \text { to } \mathrm{Fe}^{2+} \text { by } \\
\text { CA under UV or visible radiation. RSD } 2.8 \% .40 \text { samples } \mathrm{h}^{-1} \text {. }\end{array}$ & 15 \\
\hline $0.16-0.64$ & 0.066 & Total polyphenols & Detn. of total polyphenol content in 20 medicinal Brazilian plants. PA as std. & $\begin{array}{l}\text { this } \\
\text { work }\end{array}$ \\
\hline
\end{tabular}

hydroxylamine sulfate, in which residue was then able to reduce $\mathrm{Fe}(\mathrm{III})$ in a medium containing 1,10-phen [13]. Glucose was analyzed in human blood plasma and wine after its redox reaction with quinone in an immobilized glucose oxidase column yielding hydroquinone, which then reduced $\mathrm{Fe}(\mathrm{III})$ [14]. Fe(III) was photochemically reduced by citric acid upon irradiation of visible and UV light and the $\mathrm{Fe}(\mathrm{II})$ formed was determined with 1,10phen [15]. Despite these interesting strategies, the indirect determination of reducing agents weaker than ascorbic acid and tannins (such as formaldehyde, glucose and citric acid) in complex samples seems to demand more elaborate analytical procedures or consume more chemical reagents.

Lau et al. developed an accurate spectrophotometric method for the determination of tannins in tea and beer samples [16]. In that study, the reduction of $\mathrm{Fe}(\mathrm{III})$ to
$\mathrm{Fe}(\mathrm{II})$ by tannins was carried out at $80^{\circ} \mathrm{C}$ for $20 \mathrm{~min}$ and then the $\mathrm{Fe}(\mathrm{II})$ formed was reacted with 1,10-phen (at $\mathrm{pH}$ $=4.4)$ to form the orange-red $\mathrm{Fe}(\text { phen })_{3}^{2+}$ complex. However, in order to reduce the interference from other reducing compounds in these samples, it was necessary to obtain a "tannin free" solution. For this purpose, a background correction was carried out by precipitating tannins twice (with gelatine and kaolin) which rendered the method tedious and time consuming [16].

In the present work, the analytical calibration graph obtained by using pyrogallic acid as reducing agent of $\mathrm{Fe}(\mathrm{III})$, in the presence of 1,10 phen, was used to determine the total polyphenol content in aqueous extracts of twenty Brazilian medicinal plants. No background correction was needed and the absorbance values obtained (at $511 \mathrm{~nm}$ ) due to the $\mathrm{Fe}(\text { phen })_{3}^{2+}$ complexes formation, after the addition of 1,10-phen, were found to be 
proportional to the polyphenols' concentration.

All results obtained by this reaction were compared with the values obtained with the Folin-Ciocalteu reagent which was recommended by the Brazilian Pharmacopoeia for determining the total content of polyphenol in plant species [17].

Some of the plants investigated in this study have not been extensively studied but have widespread use in folk medicine in the treatment of several diseases. For these species the value of the total polyphenol content is not yet standardized, so they are not available in the Brazilian Pharmacopoeia.

The values of the antioxidant capacity of the same twenty plant species were determined using the wellknown method of the scavenging of the stable radical DPPH (2,2-diphenyl-1-picrylhydrazyl) and compared with their values of total polyphenol content.

\section{MATERIAL AND METHODS}

\subsection{Apparatus}

All spectrophotometric measurements were made in a HPUV 8453 (Agilent) spectrophotometer using a $1.0 \mathrm{~cm}$ optical path length glass cell.

\subsection{Reagents}

Reverse osmosis water (Quimis, Q842-210, Brazil) was used to prepare the solutions of analytical-grade chemicals (except when another solvent is indicated).

A $192 \mathrm{~g} \mathrm{~L}^{-1} \mathrm{Fe}\left(\mathrm{ClO}_{4}\right)_{3}$, stock solution was synthesized and standardized as described in previous studies [18]. A diluted $3.54 \mathrm{~g} \mathrm{~L}^{-1}$ working solution was prepared by accurate dilution.

A $0.101 \mathrm{~g} \mathrm{~L}^{-1}$ pyrogallic acid $\left(\mathrm{C}_{6} \mathrm{H}_{6} \mathrm{O}_{3}, \mathrm{FW} 126.11\right.$ $\mathrm{g} \cdot \mathrm{mol}^{-1}, 99 \%$, Labsynth, Brazil,) stock solution was prepared by dissolving $0.0504 \mathrm{~g}$ in $500.0 \mathrm{~mL}$. A 12.6 and $5.04 \mathrm{mg} \mathrm{L}^{-1}$ working solutions were obtained by dilution in water just before the use.

A $3.28 \mathrm{~g} \cdot \mathrm{L}^{-1} 1,10$-phenanthroline $(1,10$-phen) stock solution was prepared by dissolving $1.64 \mathrm{~g}$ of 1,10-phen monohydrate $\left(\mathrm{C}_{12} \mathrm{H}_{8} \mathrm{~N}_{2} \cdot \mathrm{H}_{2} \mathrm{O}\right.$, FW $198.26 \mathrm{~g} \cdot \mathrm{mol}^{-1}, 99.5 \%$, Merck, Brazil, ) in $10.0 \mathrm{~mL}$ ethanol $\left(\mathrm{CH}_{3} \mathrm{CH}_{2} \mathrm{OH}, \mathrm{FW}\right.$ $46.06 \mathrm{~g} \cdot \mathrm{mol}^{-1}, 99.5 \%$, Synth, Brazil) and then diluted in water in a $500.0 \mathrm{~mL}$ volumetric flask.

A $3.72 \mathrm{~g} \cdot \mathrm{L}^{-1}$ ethylenediaminetetraacetic acid (EDTA) solution was prepared by dissolving $1.86 \mathrm{~g}$ of disodium ethylenediaminetetraacetate dihydrate

$\left(\mathrm{C}_{10} \mathrm{H}_{14} \mathrm{~N}_{2} \mathrm{O}_{8} \mathrm{Na}_{2} \cdot 2 \mathrm{H}_{2} \mathrm{O}\right.$, $372.24 \mathrm{~g} \cdot \mathrm{mol}^{-1}$, 99\%, Synth, Brazil) in a $500.0 \mathrm{~mL}$ volumetric flask.

Acetate buffer solution (HAc/KAc) pH 4.6 prepared by dissolving $14.3 \mathrm{~mL}$ of glacial acetic acid $\left(\mathrm{CH}_{3} \mathrm{COOH}\right.$, FW $60.05 \mathrm{~g} \cdot \mathrm{mol}^{-1}, 99.8 \%$, Merck, Brazil) and $20 \mathrm{~g}$ of potassium acetate $\left(\mathrm{CH}_{3} \mathrm{COOK}, \mathrm{FW} 98.15 \mathrm{~g} \cdot \mathrm{mol}^{-1}, 99 \%\right.$, Merck, Brazil) in water in a $1.0 \mathrm{~L}$ volumetric flask.
The Folin-Ciocalteu (FC) reagent was prepared as described in Brazilian Pharmacopoeia [17]. $20 \mathrm{~g}$ of sodium tungstate $\left(\mathrm{Na}_{2} \mathrm{WO}_{4} \cdot 2 \mathrm{H}_{2} \mathrm{O}, \mathrm{FW} 329.86 \mathrm{~g} \cdot \mathrm{mol}^{-1}, 99 \%\right.$, Vetec, Brazil), $4.0 \mathrm{~g}$ of phosphomolybdic acid $\left(\mathrm{H}_{3} \mathrm{Mo}_{12} \mathrm{O}_{40} \mathrm{P} \cdot \mathrm{H}_{2} \mathrm{O}\right.$, FW $1825.55 \mathrm{~g} \mathrm{~mol}^{-1}, 99 \%$, Sigma, Brazil), and $10 \mathrm{~mL}$ of phosphoric acid $\left(\mathrm{H}_{3} \mathrm{PO}_{4}, \mathrm{FW} 98.00\right.$ $\mathrm{g} \cdot \mathrm{mol}^{-1}, 85 \%, \mathrm{~d}=1.88 \mathrm{~g} \cdot \mathrm{mol}^{-1}$, Merck, Brazil) were dissolved in $150 \mathrm{~mL}$ of water. This solution was heated under reflux for 2 hours and after cooling at room temperature, the solution was diluted to $200 \mathrm{~mL}$ with water. When the FC reagent is not being used it is kept in a refrigerator at $8^{\circ} \mathrm{C}$.

A $10 \%(\mathrm{~m} / \mathrm{v})$ sodium carbonate $\left(\mathrm{Na}_{2} \mathrm{CO}_{3}, \mathrm{FW} 105.99\right.$ $\mathrm{g} \cdot \mathrm{mol}^{-1}, 99 \%$, Vetec, Brazil) solution was prepared in water.

A 50\% (v/v) methyl alcohol $\left(\mathrm{CH}_{3} \mathrm{COH}, \mathrm{FW} 32.04 \mathrm{~g}\right.$ $\mathrm{mol}^{-1}, \mathrm{~d}=0.792 \mathrm{~g} \mathrm{~cm}^{-3}$, Merck, Brazil) and a $70 \%(\mathrm{v} / \mathrm{v})$ acetone $\left(\mathrm{CH}_{3} \mathrm{OCH}_{3}, \mathrm{FW} 58.08 \mathrm{~g} \cdot \mathrm{mol}^{-1}, \mathrm{~d}=0.79 \mathrm{~g} \mathrm{~cm}^{-3}\right.$, Merck, Brazil) solutions (both $1.0 \mathrm{~L}$ ) were prepared in water.

A $23.7 \mathrm{mg} \cdot \mathrm{L}^{-1}$ DPPH (2,2-diphenyl-1-picrylhydrazyl, $\mathrm{C}_{18} \mathrm{H}_{12} \mathrm{~N}_{5} \mathrm{O}_{6}$, FW $394.32 \mathrm{~g} \cdot \mathrm{mol}^{-1}$, Sigma-Aldrich) solution was prepared daily just before the use by dissolving $2.40 \mathrm{mg}$ in methyl alcohol in a $100.0 \mathrm{~mL}$ volumetric flask.

\subsection{Procedures}

\subsubsection{Sample Preparation for Polyphenol Determination}

The procedure described in the Brazilian Pharmacopoeia was used to extract the soluble polyphenol content of plant samples [17]. $0.75 \mathrm{~g}$ of dry material of each plant was transferred to a $250 \mathrm{~mL}$ erlenmeyer containing 150 $\mathrm{mL}$ of water which was maintained on a water-bath for $30 \mathrm{~min}$ at $80^{\circ} \mathrm{C}-90^{\circ} \mathrm{C}$. After cooling, the mixture was transferred to a $250.0 \mathrm{~mL}$ volumetric flask and made up with water and left the plant material being decanted. This solution was filtered and then discarding the first 50 $\mathrm{mL}$ of the filtrate. Then $5.0 \mathrm{~mL}$ of the filtrate above were transferred to a $25.0 \mathrm{~mL}$ volumetric flask which was completed with water.

\subsubsection{Sample Preparation for Antioxidant Capacity Determination}

$1.00 \mathrm{~g}$ of the dry material was transferred to a $100 \mathrm{~mL}$ beaker in which was added $40 \mathrm{~mL}$ of a $50 \%(\mathrm{v} / \mathrm{v})$ methyl alcohol aqueous solution. After homogenization, the mixture was allowed to stand for 1 hour at room temperature. This mixture was centrifuged $(15,000 \mathrm{rpm}, 15$ min, diameter $12 \mathrm{~cm}$ ) and the supernatant was transferred to a $100.0 \mathrm{~mL}$ volumetric flask. Next, $40 \mathrm{~mL}$ of a $70 \%$ $(\mathrm{v} / \mathrm{v})$ acetone aqueous solution material were added in the centrifuged. After homogenization, the mixture was also allowed to stand for 1 hour at room temperature. 
Then, this mixture was centrifuged $(15,000 \mathrm{rpm}, 15 \mathrm{~min}$, diameter $12 \mathrm{~cm}$ ) and the supernatant obtained was transferred to the same $100.0 \mathrm{~mL}$ volumetric flask. Water was used to fill the volume of this flask [19].

\subsubsection{Reference Procedure for Polyphenols Quantification (FC Reagent)}

The procedure was carried out as described in the Brazilian Pharmacopoeia for total polyphenol quantification (with a 10-fold reduction in the volume of all reagents used) [17]. A calibration graph was obtained by mixing aliquots of 100 to $700 \mu \mathrm{L}$ from a $12.6 \mathrm{mg} \cdot \mathrm{L}^{-1}$ pyrogallic acid, PA, standard solution, with $200 \mu \mathrm{L}$ of FC reagent and completed with a $10 \% \mathrm{Na}_{2} \mathrm{CO}_{3}$ solution in a $5.0 \mathrm{~mL}$ volumetric flask.

Five $\mathrm{mL}$ of the aqueous extracts of plants (item 2.3.1) were transferred to a $25.0 \mathrm{~mL}$ volumetric flask and completed with water.

The multiple standard addition method was utilized for analysis of all aqueous extracts, as follows: $100-300 \mu \mathrm{L}$ (depending on the species) of the aqueous extract were transferred into five flasks $(5.0 \mathrm{~mL})$ followed by addition of $200 \mu \mathrm{L}$ of FC reagent. In four out of five $5.0 \mathrm{~mL}$ volumetric flasks, aliquots of $100,300,500$ and $700 \mu \mathrm{L}$ of a $12.6 \mathrm{mg} \cdot \mathrm{L}^{-1}$ of PA standard solution were added and then the flasks were completed with $10 \% \mathrm{Na}_{2} \mathrm{CO}_{3}$ solution.

In both graphs (calibration and multiple standard additions with the samples) the absorbance was measured at $715 \mathrm{~nm}\left(\mathrm{~A}_{715 \mathrm{~nm}}\right)$ after $30 \mathrm{~min}$. using water as reference solution.

\subsubsection{Proposed Procedure for Polyphenols Determination $\mathrm{Fe}(\text { phen })_{3}^{2+}$ Complexes)}

The calibration graph was obtained by transferring different volumes $(0.4$ to $2.5 \mathrm{~mL})$ of $5.04 \mathrm{mg} \cdot \mathrm{L}^{-1} \mathrm{PA}$ standard solution to testing tubes $(12 \mathrm{~mm} \times 120 \mathrm{~mm})$ containing $2.5 \mathrm{~mL}$ of $3.54 \mathrm{~g} \cdot \mathrm{L}^{-1} \mathrm{Fe}\left(\mathrm{ClO}_{4}\right)_{3}$ solution. The tubes were then placed in a water bath and maintained at $80^{\circ} \mathrm{C}$ for 20 $\mathrm{min}$. After, the solutions contained in these tubes were transferred to $25.0 \mathrm{~mL}$ volumetric flasks and then were adding $2.5 \mathrm{~mL}$ of acetate buffer solution ( $\mathrm{pH} 4.6), 5.0$ $\mathrm{mL}$ of $3.28 \mathrm{~g} \cdot \mathrm{L}^{-1} 1,10$-phen and $2.5 \mathrm{~mL}$ of $3.72 \mathrm{~g} \mathrm{~L}^{-1}$ EDTA. The volume was completed with water and after cooling the absorbance measurements were made at $511 \mathrm{~nm}$.

The multiple standard addition method was used in all extracts samples analysis as follows: $100 \mu \mathrm{L}$ of the samples of aqueous extracts (item 2.3.1) were transferred to five testing tubes. In four out of five tubes, aliquots of $0.4,0.8,1.2$ and $1.6 \mathrm{~mL}$ of a $5.04 \mathrm{mg} \cdot \mathrm{L}^{-1}$ of PA standard solution were added. Next, the procedure for obtaining the calibration graph was repeated.

In both graphs (calibration and multiple standard additions with the samples) the absorbance values, after cooling, were measured at $511 \mathrm{~nm}$.

A mixture containing $354 \mathrm{mg} \cdot \mathrm{L}^{-1} \mathrm{Fe}\left(\mathrm{ClO}_{4}\right)_{3}, 656$ $\mathrm{mg} \cdot \mathrm{L}^{-1} 1,10$-phen, $372 \mathrm{mg} \cdot \mathrm{L}^{-1}$ EDTA in acetate buffer $(\mathrm{pH}=4.6)$ medium, after undergoing the above procedure, was used as reference solution.

\subsubsection{Determination of the Total Antioxidant Capacity Based on the Scavenging of the Stable Radical DPPH}

The DPPH scavenging assay for the total antioxidant capacity determination was carried out based on the procedure described by Sánchez-Moreno et al. [20]. The $\mathrm{DPPH} \bullet$ is a stable free radical in solution and its concentration can be followed by the absorbance measurements at $515 \mathrm{~nm}\left(\mathrm{~A}_{515 \mathrm{~nm}}\right)$. The decrease in absorbance value by adding aliquots of plant extract is related to the total antioxidant capacity.

Firstly, the absorbance values at $515 \mathrm{~nm}\left(\mathrm{~A}_{515 \mathrm{~nm}}\right)$ of five DPPH diluted solutions $\left(2.37-18.9 \mathrm{mg} \mathrm{L}^{-1}\right)$ obtained from the $23.7 \mathrm{mg} \mathrm{L}^{-1}$ DPPH stock solution were taken using methyl alcohol for zeroing the spectrophotometer. The DPPH calibration graph determined by linear regression was achieved by plotting the $A_{515 n m}$ values as a function of DPPH concentration.

$$
\mathrm{A}_{515 n m}=a+b \times \mathrm{DPPH}
$$

In order to evaluate the total antioxidant capacity of plant extracts the following procedure was performed. A control solution was prepared adding $0.125 \mathrm{~mL}$ of an aqueous solution containing methyl alcohol and acetone $(40 \mathrm{~mL}$ of $50 \%(\mathrm{v} / \mathrm{v})$ methyl alcohol $+40 \mathrm{~mL}$ of $70 \%$ $(\mathrm{v} / \mathrm{v})$ acetone in $100 \mathrm{~mL})$ in a $5.00 \mathrm{~mL}$ volumetric flask and the volume completed with the $23.7 \mathrm{mg} \cdot \mathrm{L}^{-1} \mathrm{DPPH}$ solution. The value corresponding to half of the $A_{515 \mathrm{~nm}}$ of the control solution is substituted in Equation (1) to obtain the corresponding DPPH value (in $\mathrm{mg} \cdot \mathrm{L}^{-1}$ ), and the respective value in $\mathrm{g}$ of DPPH is calculated.

Another calibration curve is obtained in the presence of plant extracts. For each plant extract (item 2.3.2) four different diluted solutions varying from $0.05-0.5 \mathrm{mg} \cdot \mathrm{L}^{-1}$ of dry material were prepared in the $50 \%$ methyl alcohol aqueous solution. A $0.125 \mathrm{~mL}$ of these plant extract dilution were transfer to a $5.00 \mathrm{~mL}$ volumetric flask and the volume completed with the $23.7 \mathrm{mg} \cdot \mathrm{L}^{-1} \mathrm{DPPH}$ solution. The $A_{515 \mathrm{~nm}}$ values were taken after 15 minutes using methyl alcohol to zeroing the spectrophotometer. The extract calibration graph was obtained by plotting these $\mathrm{A}_{515 \mathrm{~nm}}$ values as a function of the dry material solutions where $C_{D M}$ is in $\mathrm{mg} \cdot \mathrm{L}^{-1}$ as in Equation (2). It shows the decrease of the absorbance values due to the scavenging of the DPPH by the polyphenols.

$$
\mathrm{A}_{515 \mathrm{~nm}}=a-b \times \mathrm{C}_{\mathrm{DM}}
$$

In order to express the total antioxidant capacity, the 
half value of $A_{515 \mathrm{~nm}}$ of the control solution (obtained with DPPH solution without addition of plant extracts) is substituted in Equation (2). The value found corresponds to the dry material sample required to reduce by $50 \%$ the initial concentration of DPPH $\left(\mathrm{EC}_{50}\right)$. The $\mathrm{EC}_{50}$ results were expressed as g DPPH/g dry material (Table 2).

Table 2. Total polyphenols quantification using the Folin-Ciocalteu reagent and the $\mathrm{Fe}(\mathrm{phen})_{3}^{2+}$ complexes, expressed as pyrogallic acid.

\begin{tabular}{|c|c|c|c|c|c|c|}
\hline \multirow[t]{2}{*}{ Plant } & \multirow[t]{2}{*}{$\begin{array}{c}\text { Common } \\
\text { Brazilian name }\end{array}$} & \multirow[t]{2}{*}{ Part used } & \multirow[t]{2}{*}{ Use in folk medicine [30] } & \multicolumn{2}{|c|}{ Total polyphenols content ${ }^{\mathrm{a}}$} & \multirow{2}{*}{$\begin{array}{c}\begin{array}{c}\text { Antioxidant } \\
\text { capacity }\end{array} \\
\mathrm{EC}_{50} \mathrm{~b}[19,20]\end{array}$} \\
\hline & & & & Folin-Ciocalteu [17] & $\mathrm{Fe}(\text { phen })_{3}{ }^{2+}$ & \\
\hline Annona muricata $\mathrm{L}$. & Graviola & Leaves & Anti-diarrhea; against spasms & $1.90 \pm 0.06$ & $1.06 \pm 0.80$ & 9.09 \\
\hline $\begin{array}{l}\text { Baccharis trimera } \\
\text { (Less.) DC. }\end{array}$ & Carqueja & $\begin{array}{l}\text { Leaves and } \\
\text { stalk }\end{array}$ & $\begin{array}{l}\text { Female infertility and male impotence; } \\
\text { liver problems; stomach dysfunctions }\end{array}$ & $0.83 \pm 0.09$ & $0.27 \pm 0.05$ & 2.44 \\
\hline $\begin{array}{l}\text { Bauhinia splendens } \\
\text { Kunth }\end{array}$ & Escada de Jabuti & i Barks & Hemorrhoids and anti-rheumatic & $1.42 \pm 0.14$ & $1.33 \pm 0.03$ & 25.0 \\
\hline Casearia sylvestris $\mathrm{Sw}$. & Guaçatonga & Barks & $\begin{array}{l}\text { Burns injuries; herpes; skin injuries; } \\
\text { gastritis }\end{array}$ & $1.90 \pm 0.14$ & $1.40 \pm 0.30$ & 0.182 \\
\hline $\begin{array}{l}\text { Carapa guianensis } \\
\text { Aubl. }\end{array}$ & Andiroba & Barks & Ulcers; bronchitis; cicatrizant & $2.55 \pm 0.19$ & $0.59 \pm 0.05$ & 25.0 \\
\hline $\begin{array}{l}\text { Cordia ecalyculata } \\
\text { Vell. }\end{array}$ & Porangaba & Leaves & Diuretic & $1.30 \pm 0.08$ & $2.05 \pm 0.66$ & 8.33 \\
\hline $\begin{array}{l}\text { Costus spicatus (Jacq.) } \\
\text { Sw. }\end{array}$ & Canarana & Leaves & Pain and swelling & $0.47 \pm 0.10$ & $0.49 \pm 0.20$ & 14.3 \\
\hline $\begin{array}{l}\text { Dipteryx odorata } \\
\text { (Aubl.) Willd. }\end{array}$ & Cumaru & Seeds & Spasm; headache; & $1.40 \pm 0.12$ & $0.75 \pm 0.21$ & 14.2 \\
\hline $\begin{array}{l}\text { Geissospermum laeve } \\
\text { (Vell.) Miers }\end{array}$ & Pau Pereira & Barks & Fever; stomachache; dizziness & $1.53 \pm 0.06$ & $0.16 \pm 0.03$ & 4.55 \\
\hline $\begin{array}{l}\text { Hamamelis virginiana } \\
\mathrm{L} .\end{array}$ & Hamamelis & Leaves & $\begin{array}{c}\text { Hemorrhoids, anal eczema, bleeding, } \\
\text { angina }\end{array}$ & $3.12 \pm 0.08$ & $3.11 \pm 0.38$ & 0.48 \\
\hline $\begin{array}{l}\text { Himatanthus drasticus } \\
\text { (Mart.) Plumel }\end{array}$ & Sucuúba & Barks & Inflammation; gastritis & $0.57 \pm 0.06$ & $0.46 \pm 0.04$ & 0.97 \\
\hline Hymenaea courbaril L. & Jatobá & Barks & Cough; bronchitis & $1.41 \pm 0.19$ & $1.43 \pm 0.50$ & 14.2 \\
\hline Lippia grandis Shauer & Salva de Marajó & Leaves & Headache; stomachache & $2.40 \pm 0.10$ & $2.71 \pm 0.20$ & 9.09 \\
\hline $\begin{array}{c}\text { Maytenus ilicifolia } \\
\text { Mart. ex Reissek }\end{array}$ & Espinheira Santa & Leaves & $\begin{array}{l}\text { Skin cancer; ulcers; indigestion; chronic } \\
\text { gastritis; dyspepsia }\end{array}$ & $0.70 \pm 0.04$ & $0.71 \pm 0.10$ & 7.69 \\
\hline $\begin{array}{l}\text { Salacia impressifolia } \\
\text { (Miers) A.C. Sm. }\end{array}$ & Miraruira & Stalks & Diabetes & $3.52 \pm 0.39$ & $1.70 \pm 0.48$ & 33.3 \\
\hline $\begin{array}{l}\text { Schinus terebinthifolia } \\
\text { Raddi }\end{array}$ & Aroeira & Leaves & Washing wounds; ulcers & $5.57 \pm 0.52$ & $3.52 \pm 0.60$ & 100 \\
\hline $\begin{array}{c}\text { Stachytarpheta } \\
\text { cayennensis (Rich.) } \\
\text { Vahl }\end{array}$ & Gervão & Leaves & $\begin{array}{l}\text { Stomach tonic and stimulant of gastric } \\
\text { functions; anthelmintic }\end{array}$ & $1.92 \pm 0.05$ & $1.72 \pm 0.04$ & 9.97 \\
\hline $\begin{array}{l}\text { Stryphnodendron } \\
\text { adstringens (Mart.) } \\
\text { Coville }\end{array}$ & Barbatimão & Barks & $\begin{array}{l}\text { Leucorrhoea; hemorrhoids; bleeding; } \\
\text { diarrhea }\end{array}$ & $11.8 \pm 0.3$ & $11.9 \pm 1.9$ & 1.59 \\
\hline Plantago major L. & Tanchagem & Leaves & Diuretic; anti-rheumatic, bronchitis & $1.20 \pm 0.08$ & $0.90 \pm 0.13$ & 0.29 \\
\hline Vismia duckei Maguire & Lacre & Leaves & Anti-rheumatic; dermatosis & $0.40 \pm 0.06$ & $0.12 \pm 0.02$ & 2.78 \\
\hline
\end{tabular}

\footnotetext{
${ }^{a}$ average and standard deviation values expressed as g pyrogallic acid/100 g dry material. ${ }^{\mathrm{b}} \mathrm{EC}_{50}$ expressed as $\mathrm{g} \mathrm{DPPH} / \mathrm{g}$ dry material.
} 


\section{RESULTS AND DISCUSSION}

\subsection{Chemical Features}

The spectrophotometric method proposed to measure the total content of polyphenols in aqueous vegetable extracts is based on the reduction of $\mathrm{Fe}$ (III) by polyphenolic compounds (PC's) in a water bath at $80^{\circ} \mathrm{C}$ for $20 \mathrm{~min}$. The $\mathrm{Fe}$ (II) formed reacts with the 1,10-phen ligand yielding the reddish-orange $\mathrm{Fe}(\text { phen })_{3}^{2+}$ complexes according to Equation (3):

$$
\mathrm{Fe}(\text { phen })_{3}^{3+}+\mathrm{PC} \text { 's } \rightarrow \mathrm{Fe}(\text { phen })_{3}^{2+}+\text { PC's oxidized (3) }
$$

In the proposed procedure the ratio "total metalic ion: ligand" = 1:3 was kept, with $10 \%$ excess of the latter. Thus, in all working solutions the concentrations of metal ion and ligand were $354 \mathrm{mg} \cdot \mathrm{L}^{-1} \mathrm{Fe}(\mathrm{III})$ and 656 $\mathrm{mg} \cdot \mathrm{L}^{-1} 1,10$-phen.

Most studies involving the formation of $\mathrm{Fe}(\mathrm{phen})_{3}^{2+}$ kept the $\mathrm{pH}$ of working solution between 3 to 6 , so in the present study acetate buffer was used to maintain the $\mathrm{pH}$ at 4.6. Addition of a suitable masking agent, like EDTA, is needed for the complexion of the unreacted residual $\mathrm{Fe}(\mathrm{III})$ in order to avoid the absorbance interference of $\mathrm{Fe}(\text { phen })_{3}^{3+}[3,16]$.

The order of addition of reagents (Fe(III) $+\mathrm{PA}+$ buffer solution + EDTA + 1,10-phen) is required to obtain consistent and reproducible results. It was noted that the development of a color solution is very slow at room temperature, so the final solution was kept in a water bath $\left(80^{\circ} \mathrm{C}\right.$ for $20 \mathrm{~min}$.) as done in previous works [16].

The absorption spectra of the Fe(III) solution in presence of 1,10-phen before and after addition of PA standard solution are represented in the Figure 1. The absorbance value at $511 \mathrm{~nm}, \mathrm{~A}_{511 \mathrm{~nm}}$, due to the $\mathrm{Fe}(\text { phen })_{3}^{2+}$ complexes is linear with PA concentration from 0.16 to $0.64 \mathrm{mg} \cdot \mathrm{L}^{-1}$, described by the equation $\mathrm{A}_{511 \mathrm{~mm}}=0.0929+$ $1.172 \times \mathrm{PA}(\mathrm{r}=0.994, \mathrm{n}=6)$. The limit of detection, $\mathrm{LD}$, calculated as three times the standard deviation of the intercept, divided by the slope of the regression equation, obtained by the least-squares method for a calibration graph, was $0.041 \mathrm{mg} \cdot \mathrm{L}^{-1}$. The relative standard deviation, $\mathrm{RSD}$, for 10 measurements of $0.24 \mathrm{mg} \cdot \mathrm{L}^{-1} \mathrm{PA}$ standard solution was $1.3 \%$. The angular coefficient, defined as apparent absorptivity for PA (at $511 \mathrm{~nm})$ was $(1.18 \pm$ $0.11) \mathrm{L} \cdot \mathrm{cm}^{-1} \mathrm{mg}^{-1}$ for 12 calibration graphs (RSD $8.6 \%$ ) which makes the proposed method very sensitive to polyphenol-rich complex samples such as plant extracts $[18,21]$.

\subsection{Interference Study}

In a previous published article dealing with the determination of tannins in tea and beer samples using the



Figure 1. Absorption spectra of: (a) $=\mathrm{Fe}(\mathrm{III}) 354 \mathrm{mg} \mathrm{\textrm {L } ^ { - 1 } +}$ acetate buffer solution $\mathrm{pH}=4.6$ (HAc $0,025 \mathrm{~mol} \mathrm{~L}^{-1} / \mathrm{KAc}$ $\left.0,020 \mathrm{~mol} \mathrm{~L}^{-1}\right)+1,10$-phen $656 \mathrm{mg} \mathrm{L}^{-1}+$ EDTA $372 \mathrm{mg} \mathrm{L}^{-1}$, $(\mathrm{b}$ to $\mathrm{g})=(\mathrm{a})+$ Pyrogallic acid $\left(\mathrm{mg} \mathrm{L}^{-1}\right)$ 0.8, 0.16, 0.24, 0.32, 0.40 and 0.50 , respectively. Absorbance measurements using water as reference solution. Inset figure: Calibration graph for pyrogallic acid using the absorbance at $510 \mathrm{~nm}$ of $\mathrm{Fe}(\mathrm{phen})_{3}{ }^{2+}$ complexes $(\mathrm{b}=1.0 \mathrm{~cm})$.

$\mathrm{Fe}(\text { phen })_{3}^{2+}$ complexes, it was pointed out that most of the compounds normally found in those samples showed no interference [16]. So in that study a background correction based on the precipitation of tannins with gelatin and kaolin was carried out to minimize interference due to other reducing substances (resulting in a "free tannin solution") before the absorbance measurements.

In the present work the influence of some non-phenolic compounds usually present in aqueous plants extracts was verified regarding to the reduction of $\mathrm{Fe}(\mathrm{III})$ to $\mathrm{Fe}(\mathrm{II})$ before the addition of 1,10-phen. Solutions containing one fixed concentration of PA $\left(0.252 \mathrm{mg} \cdot \mathrm{L}^{-1}\right)$ and three solutions containing this PA solution plus three known concentrations $\left(0.252,2.52\right.$ and $\left.6.31 \mathrm{mg} \cdot \mathrm{L}^{-1}\right)$ of the possible interfering species were analyzed following the proposed procedure (item 2.3.3.).

The interference criterion adopted was that the $\mathrm{A}_{511 \mathrm{~mm}}$ value of the mixture varied more than $10 \%$ from the $\mathrm{A}_{511 \mathrm{~nm}}$ value obtained for the $0.25 \mathrm{mg} \cdot \mathrm{L}^{-1}$ PA solution alone.

Ascorbic acid (AA), a strong reducing agent, reduced $\mathrm{Fe}(\mathrm{III})$ to $\mathrm{Fe}(\mathrm{II})$ and a positive interference was observed when it was present in a PA:AA $=1: 1$ ratio $(0.252 / 0.252$ $\mathrm{mg} \mathrm{L}^{-1}$ ).

Citric acid (CA) also showed a positive interference when present in a CA:AA $=1: 1$ ratio $(0.252 / 0.252 \mathrm{mg}$ $\mathrm{L}^{-1}$ ), which could be probably attributed to the photochemical reduction of $\mathrm{Fe}$ (III) to $\mathrm{Fe}(\mathrm{II})$ in the presence of CA [15].

Saponin has also shown a positive interference when present in 1:1 ratio.

Regarding sugars, interference was observed for fruc- 
tose, glucose, lactose, sucrose and galactose from a 10fold excess PA: sugars ratio $=0.252 / 2.50 \mathrm{mg} \cdot \mathrm{L}^{-1}$.

Nevertheless, the concentrations of those substances in aqueous extracts of plants species obtained from dry materials are usually lower than the polyphenols, then none significant interference of these substances is expected. Besides, for the polyphenols quantification by the present procedure, dilutions from 5 to 25 -fold are necessary (item 2.3.1), which would probably prevent any possible interference that could arise from any reducing sugars, saponin, ascorbic and citric acids.

\subsection{Statistical Treatment}

Since we are dealing with samples of variable composition, the paired $t$-test [22] was performed for statistical comparison of the results for polyphenols quantification, represented by g PA/100 g of dry material, obtained with proposed method ( $\mathrm{Fe}(\text { phen })_{3}^{2+}$ complexes) and accepted method (FC reagent). As can be seen in Table 2, the $t$-test value obtained (1.52) is less than the value tabulated (1.63) meaning that there is no statistically significant difference for the species analyzed.

\subsection{Recovery Study}

The recovery rate experiments were accomplished by spiking the sample with three different known amounts of [PA] standard solution, and the [PA] added was determined using the calibration graph "absorbance $v$ s. [PA] standard solution".

The values obtained for the rates of recovery (Table 3) ranged from $61 \%$ - 121\% (average 96\%), which can be considered reasonable in complex samples as plant extracts.

\subsection{Antioxidant Capacity}

It can be noted from Table 2 that the DPPH radical scavenging activities for the analyzed species (excluding Stryphnodendron adstringens (Mart.) Coville) are polyphenol content-dependent and decreased in the following order: Schinus terebinthifolia Raddi > Salacia impressifolia (Miers) A.C. Sm. > Bauhinia splendens Kunth $\approx$ Carapa guianensis Aubl> Costus spicatus (Jacq.) Sw. $\approx$ Dipteryx odorata (Aubl.) Willd. $\approx$ Hymenaea coubaril L. $>$ Stachytarpheta cayennensis (Rich.) Vahl $\approx$ Annona muricata L. > Lippia grandis Shauer > Cordia ecalyculata Vell . $\approx$ Maytenus ilicifolia Mart. ex Reissek > Geissospermum laeve (Vell.) Miers > Vismia duckei Maguire $\approx$ Baccharis trimera (Less.) DC. $>$ Stryphnodendron adstringens (Mart.) Coville $\approx$ Himatanthus drasticus (Mart.) Plumel > Hamamelis virginiana L. > Plantago major L. $\approx$ Casearia sylvestris $\mathrm{Sw}$.

A significant correlation $(\mathrm{r}=0.785)$ was found between the antioxidant capacity values (g DPPH/g dry material $/ g$ ) and the values of the total polyphenols content (g PA/100 g dry material) obtained with the FC reagent. Considering the values of the total polyphenols content obtained with the $\mathrm{Fe}(\text { phen })_{3}^{2+}$ complexes, this correlation is somewhat lower $(\mathrm{r}=0.520)$ but still significant. Those results show that the $\mathrm{Fe}(\text { phen })_{3}^{2+}$ complexes could be also used to determine the antioxidant capacity of plant extracts.

\subsection{Critical Considerations about the Use of the $\mathrm{Fe}(\text { phen })_{3}^{2+}$ Complexes and the FC Reagent in the Analysis of Total Polyphenol Content.}

Herein are highlighted some relevant aspects of the use of $\mathrm{Fe}(\text { phen })_{3}^{2+}$ complexes and $\mathrm{FC}$ reagent in the analysis of the polyphenol content from the chemical point of view on which they are based.

a) In order to have quantitative oxidation of the phenolic compounds with the formation of the $\mathrm{Fe}(\text { phen })_{3}^{2+}$ complexes, the $\mathrm{pH}$ value should be between $2-9$. In the majority of studies, the $\mathrm{pH}$ was kept between $3-6$ using acetate or citrate buffer solutions. In the present study the $\mathrm{pH}$ was maintained at 4.6 with acetate buffer which is most commonly employed. Besides, citric acid was found to reduce $\mathrm{Fe}^{3+}$ to $\mathrm{Fe}^{2+}$ by the action of light [15]. In contrast, analyses with $\mathrm{FC}$ reagent must be conducted in an alkaline medium $(\mathrm{pH}=10)$ which is easily achieved by the addition of sodium carbonate solution. At this $\mathrm{pH}$ the phenolic compounds are present as phenolates which are easier to oxidize. This may be the cause of obtaining results generally higher than those obtained with other methods [23-25]. Although the $\mathrm{nH}$ ranoes in which these two reactants $\left(\mathrm{Fe}(\text { phen })_{3}^{2+}\right.$ complexes and $\mathrm{FC}$ reagent) used are different, both methods have low selectivity in the analysis of polyphenols, for example, the specific identification of any polyphenol in a complex mixture is not possible.

b) It has been mentioned that the reduction of $\mathrm{Fe}$ (III) involves slow kinetic processes and that could hinder the quantification of reducing compounds in complex samples. In fact, it can be one of the reasons for the small number of analytical methods available in the literature using the $\mathrm{Fe}(\text { phen })_{3}^{2+}$ complexes for determining analytes that are potentially reducing agents (Table 1). The reduction of $\mathrm{Fe}(\mathrm{III})$ by cysteine in a medium containing 1,10-phen occurs slowly, but is accelerated in the presence of $\mathrm{Cu}$ (II) as a catalyst. This led to the development of a flow injection analytical method for spectrophotometric determination of copper [26]. The use of catalysts could be a good alternative for the development of analytical methods for other weak reducing agents. However, the procedure here presented for the determination of polyphenol content was carried out in a water bath at $80^{\circ} \mathrm{C}$ for 20 minutes and this incubation period 
Table 3. Recovery rates from aqueous extracts of twenty Brazilian medicinal plants obtained with three different quantities added of pyrogallic acid (PA) using the $\mathrm{Fe}(\text { phen })_{3}^{2+}$ complexes.

\begin{tabular}{|c|c|c|c|c|c|}
\hline \multirow[b]{2}{*}{ Plants } & \multirow[b]{2}{*}{ Common Brazilian name } & \multicolumn{2}{|c|}{ PA concentration $\left(\mathrm{mg} \mathrm{L}^{-1}\right)$} & \multirow[b]{2}{*}{ Found } & \multirow[b]{2}{*}{ Recovery (\%) } \\
\hline & & Diluted aqueous extracts sample & Added & & \\
\hline \multirow{3}{*}{ Annona muricata $\mathrm{L}$} & \multirow{3}{*}{ Graviola } & 0.120 & 0.159 & 0.120 & 75 \\
\hline & & & 0.240 & 0.183 & 76 \\
\hline & & & 0.319 & 0.212 & 66 \\
\hline \multirow{3}{*}{ Baccharis trimera (Less.) DC. } & \multirow{3}{*}{ Carqueja } & 0.252 & 0.0794 & 0.0820 & 103 \\
\hline & & & 0.240 & 0.266 & 111 \\
\hline & & & 0.319 & 0.330 & 104 \\
\hline \multirow{3}{*}{$\begin{array}{l}\text { Bauhinia splendens } \\
\text { Kunth }\end{array}$} & \multirow{3}{*}{ Escada de Jabuti } & 0.0744 & 0.0794 & 0.0845 & 106 \\
\hline & & & 0.240 & 0.221 & 92 \\
\hline & & & 0.319 & 0.314 & 98 \\
\hline \multirow{3}{*}{ Casearia sylvestris $\mathrm{Sw}$. } & \multirow{3}{*}{ Guaçatonga } & 0.161 & 0.159 & 0.102 & 64 \\
\hline & & & 0.240 & 0.146 & 61 \\
\hline & & & 0.319 & 0.272 & 85 \\
\hline \multirow{3}{*}{ Carapa guianensis Aubl } & \multirow{3}{*}{ Andiroba } & 0.248 & 0.159 & 0.140 & 88 \\
\hline & & & 0.240 & 0.238 & 99 \\
\hline & & & 0.319 & 0.335 & 105 \\
\hline \multirow{3}{*}{ Cordia ecalyculata Vell. } & \multirow{3}{*}{ Porangaba } & 0.0668 & 0.159 & 0.129 & 81 \\
\hline & & & 0.240 & 0.236 & 98 \\
\hline & & & 0.319 & 0.235 & 74 \\
\hline \multirow{3}{*}{ Costus spicatus (Jacq.) Sw. } & \multirow{3}{*}{ Canarana } & 0.0492 & 0.159 & 0.165 & 104 \\
\hline & & & 0.240 & 0.232 & 97 \\
\hline & & & 0.319 & 0.276 & 87 \\
\hline \multirow{3}{*}{ Dipteryx odorata (Aubl.) Willd. } & \multirow{3}{*}{ Cumaru } & 0.163 & 0.159 & 0.130 & 82 \\
\hline & & & 0.240 & 0.250 & 104 \\
\hline & & & 0.319 & 0.348 & 109 \\
\hline \multirow{3}{*}{$\begin{array}{c}\text { Geissospermum } \\
\text { laeve (Vell.) Miers }\end{array}$} & \multirow{3}{*}{ Pau Pereira } & 0.0706 & 0.0794 & 0.0858 & 108 \\
\hline & & & 0.159 & 0.163 & 102 \\
\hline & & & 0.319 & 0.351 & 110 \\
\hline & & 0.0387 & 0.0794 & 0.0782 & 98 \\
\hline Hamamelis virginiana $\mathrm{L}$. & Hamamélis & & 0.159 & 0.140 & 88 \\
\hline & & & 0.240 & 0.194 & 81 \\
\hline & & 0.182 & 0.159 & 0.169 & 106 \\
\hline $\begin{array}{l}\text { Himatanthus drasticus } \\
\text { (Mart.) Plumel }\end{array}$ & Sucuúba & & 0.240 & 0.256 & 107 \\
\hline & & & 0.319 & 0.300 & 94 \\
\hline & & 0.161 & 0.159 & 0.139 & 87 \\
\hline Hymenaea courbaril $\mathrm{L}$. & Jatobá & & 0.240 & 0.230 & 96 \\
\hline & & & 0.319 & 0.288 & 90 \\
\hline & & 0.337 & 0.159 & 0.141 & 89 \\
\hline Lippia grandis Shauer & Salva-de- Marajó & & 0.240 & 0.264 & 109 \\
\hline & & & 0.319 & 0.329 & 103 \\
\hline & Fsninheira_Santa & 0.184 & 0.159 & 0.146 & 92 \\
\hline $\begin{array}{l}\text { Maytenus ilicifolia } \\
\text { Mart. ex Reissek }\end{array}$ & Loppinteril d-Salla & & 0.240 & 0.256 & 107 \\
\hline & & & 0.319 & 0.334 & 105 \\
\hline & & 0.214 & 0.159 & 0.125 & 79 \\
\hline $\begin{array}{l}\text { Salacia impressifolia } \\
\text { (Miers) A.C. Sm. }\end{array}$ & Miraruira & & 0.240 & 0.256 & 107 \\
\hline & & & 0.319 & 0.375 & 117 \\
\hline
\end{tabular}




\begin{tabular}{|c|c|c|c|c|c|}
\hline \multirow{3}{*}{$\begin{array}{c}\text { Schinus terebinthifolia } \\
\text { Raddi }\end{array}$} & \multirow{3}{*}{ Aroeira } & 0.0933 & 0.159 & 0.166 & 105 \\
\hline & & & 0.240 & 0.253 & 106 \\
\hline & & & 0.319 & 0.317 & 99 \\
\hline \multirow{3}{*}{$\begin{array}{c}\text { Stachytarpheta } \\
\text { cayennensis (Rich.) Vahl }\end{array}$} & \multirow{3}{*}{ Gervão } & 0.206 & 0.159 & 0.144 & 90 \\
\hline & & & 0.240 & 0.206 & 86 \\
\hline & & & 0.319 & 0.289 & 91 \\
\hline \multirow{3}{*}{$\begin{array}{l}\text { Stryphnodendron } \\
\text { adstringens (Mart.) } \\
\text { Coville }\end{array}$} & \multirow{3}{*}{ Barbatimão } & 0.232 & 0.159 & 0.184 & 116 \\
\hline & & & 0.240 & 0.237 & 99 \\
\hline & & & 0.319 & 0.275 & 86 \\
\hline \multirow{3}{*}{ Plantago major $\mathrm{L}$. } & \multirow{3}{*}{ Tanchagem } & 0.185 & 0.159 & 0.146 & 92 \\
\hline & & & 0.240 & 0.235 & 98 \\
\hline & & & 0.319 & 0.320 & 100 \\
\hline \multirow{3}{*}{$\begin{array}{l}\text { Vismia duckei } \\
\text { Maguire }\end{array}$} & \multirow{3}{*}{ Lacre } & 0.150 & 0.0794 & 0.0706 & 88 \\
\hline & & & 0.240 & 0.286 & 119 \\
\hline & & & 0.319 & 0.387 & 121 \\
\hline
\end{tabular}

should allow all reducing compounds (even the weaker) to react completely with $\mathrm{Fe}(\mathrm{III})$. This could explain the reasonable agreement between the total polyphenol content values obtained with the $\mathrm{Fe}(\mathrm{phen})_{3}{ }^{2+}$ complexes and the FC reagent (Table 2). Moreover, such heating step makes the unnecessary use of surfactants (like cetyltrimethylammonium bromide), as previously claimed in determining polyphenols in tea samples [27].

c) The color of the solution of the $\mathrm{Fe}(\text { phen })_{3}^{2+}$ complexes is very enduring. When stored in polyethylene bottles, the orange red solution remains unchanged for over a month outside the refrigerator (even in daylight). The reaction with the FC reagent is based on the reduction of phosphomolybdic-phosphotungstic acid forming a blue color complex which quickly fades.

d) The preparation of the FC reagent is very timeconsuming. One of the ways of preparing it uses sodium tungstate $\left(\mathrm{Na}_{2} \mathrm{WO}_{4} \cdot 2 \mathrm{H}_{2} \mathrm{O}\right)$, phosphomolybdic acid $\left(\mathrm{H}_{3} \mathrm{Mo}_{12} \mathrm{O}_{40} \mathrm{P} \times \mathrm{H}_{2} \mathrm{O}\right)$ and phosphoric acid $\left(\mathrm{H}_{3} \mathrm{PO}_{4}\right)$ and it is necessary to keep the mixture of reactants boiling under reflux for 2 hours. Another way utilizes sodium tungstate $\left(\mathrm{Na}_{2} \mathrm{WO}_{4} \cdot 2 \mathrm{H}_{2} \mathrm{O}\right)$, sodium molybdate

$\left(\mathrm{Na}_{2} \mathrm{MoO}_{4} \cdot 2 \mathrm{H}_{2} \mathrm{O}\right)$, hydrochloric acid $(\mathrm{HCl})$ and lithium sulfate $\left(\mathrm{Li}_{2} \mathrm{SO}_{4} \cdot 4 \mathrm{H}_{2} \mathrm{O}\right)$. In this case, it is necessary to boil under reflux for 10 hours. Alternatively, the ligand used in the proposed procedure (1,10-phen) is easily prepared by dissolving in a hydroethanolic solution (see item 2.2).

e) The reagents used in the proposed method (ferric salt, 1,10-phen, acetate buffer and EDTA) are less expensive and more available than those used to prepare the $\mathrm{FC}$ reagent.

f) If necessary, the $\mathrm{Fe}(\text { phen })_{3}^{2+}$ complexes can be extracted in organic solvents (chloroform, nitrobenzene, etc) with large anions (e.g., any long-chain alkyl sulphate or sulfonate) or even using $\mathrm{ClO}_{4}^{-}$[28]. An analytical step involving extraction can increase the sensitivity of the analyte under investigation.

g) When using the $\mathrm{Fe}(\text { phen })_{3}^{2+}$ complexes, the order of addition of reactants is mandatory. Previous studies have shown that complete reduction to $\mathrm{Fe}$ (III) is most easily accomplished by adding the reagents in the following order: $\mathrm{Fe}(\mathrm{III})+$ reducing agent $+1,10$-phen + buffer [16]. In the present study the order was: Fe(III) + pyrogallic acid (or plant extract) + acetate buffer solution + EDTA + 1,10-phen, otherwise, discordant and nonreproducible results were obtained. For measurements using FC reagent, the order should be: pyrogallic acid (or plant extract) + FC reagent + sodium carbonate [25]

h) Analysis with FC reagent produces residue which is not generally recycled and needs to be properly disposed. Conversely, 1,10-phen can be recycled and even reused if the residue obtained after several analyzes is separately collected and concentrated. The residue is acidified with concentrated $\mathrm{H}_{2} \mathrm{SO}_{4}$ and the solution obtained is boiled in order to decompose the complex. Then, $\mathrm{CuSO}_{4}$ solution is added until complete precipitation of

$\mathrm{Cu}$ (phen) $\mathrm{SO}_{4} \cdot 2 \mathrm{H}_{2} \mathrm{O}$. The precipitate is collected, washed with $\mathrm{H}_{2} \mathrm{SO}_{4}$ and with water, and then dissolved in a $\mathrm{NH}_{4} \mathrm{OH}$ solution. A 1,10-phen liberated is extracted from this solution by shaking with $\mathrm{CHCl}_{3}$ and being isolated by evaporation [1].

Given these observations, the spectrophotometric procedure proposed here to evaluate the total content of polyphenols in the aqueous extracts of plants is simple, easily operated and can be carried out with common laboratory equipment. The reagent used (i.e. 1,10-phen) is less expensive and easier to prepare than the FC reagent. Moreover, it is suitable for routine analysis and may be applied to aqueous plant extract samples containing low levels of polyphenols. 


\section{ACKNOWLEDGEMENTS}

The authors acknowledge the financial support from Brazilian agencies FAPESP (Fundação de Amparo à Pesquisa do Estado de São Paulo), CNPq (Conselho Nacional de Pesquisa e Desenvolvimento Tecnológico as CT-Agro and PPBio projects) and FAPEAM (Fundação de Amparo à Pesquisa do Estado do Amazonas) and CENBAM-CNPqMCTI (Instituto Nacional de Ciência e Tecnologia de Estudos Integrados da Biodiversidade Amazônica).

\section{REFERENCES}

[1] Schilt, A.A. (1969) Colorimetric reagents. In: Belcher, R. and Freiser, H., Eds., Analytical Applications of 1,10Phenanthroline and Related Compounds, Pergamon Press, DeKalb, 56.

[2] Smith, R.M. and Martell, A.E. (2004) NIST critically selected stability constants of metal complexes database 46, Version 8.0. National Institute of Standards and Technology, Gaithersburg.

[3] Lau, O.W. and Luk, S.F. (1987) Spectrophotometric determination of ascorbic acid in canned fruit juices, cordials, and soft drinks with iron(III) and 1,10-phenanthroline as reagents. Association of Official Analytical Chemists, 70, 518-520.

[4] Huang, B., Luo, Z., Fang, Y. and Lin, J. (1999) Spectrophotometric determination of vitamin $\mathrm{C}$ in fruits and vegetables by $\mathrm{Fe}(\mathrm{II})-1,10$-phenanthroline-bromopyrogallol red system. Huaxue Shijie, 40, 319-321.

[5] Luque-Perez E., Rios A. and Valcarcel, M. (2000) Flow injection spectrophotometric determination of ascorbic acid in soft drinks and beer. Fresenius' Journal of Analytical Chemistry, 366, 857-862. http://dx.doi.org/10.1007/s002160051585

[6] Ghasemi, J., Seifi, S., Sharifi, M., Ghorbani, R. and Amini, A. (2004) Simultaneous kinetic spectrophotometric determination of ascorbic acid and L-cysteine by $\mathrm{H}$ point standard addition method. Microchimica Acta, 48, 259-265. http://dx.doi.org/10.1007/s00604-004-0270-y

[7] Tomas, C., Celeste, M., Cladera, A., Gomez, E., Estela, J.M. and Cerda, V. (1993) A new flow-injection spectrophotometric method for the determination of tannins in tea and beer using iron(III) and 1,10-phenanthroline. Food Chemistry, 47, 201-204. http://dx.doi.org/10.1016/0308-8146(93)90244-A

[8] Qu, X., Zhou, J., Yin, H. and Sun, Y. (2000) Flow injection-kinetic spectrophotometry for the determination of tannic acid in hops. Fenxi Huaxue, 28, 820-824.

[9] Wei, Y., Zhang, X., Li, C., Yu, C. and Liu, L. (2011) Determination of tannins in tannery wastewater by flow injection spectrophotometry. Zhongguo Pige, 40, 29-32.

[10] Memon, N., Bhanger, M.I., Memon, M.A. and Memon, M.H. (2004) Flow injection spectrophotometric determination of $\alpha$-tocopherol in microemulsion reaction medium using $\mathrm{Fe}(\mathrm{III})-1,10$ phenanthroline as an oxidant. $A C G C$ Chemical Research Communications, 17, 52-59.

[11] Rishi, L., Jadoon, S., Waseem, A., Yaqoob, M. and Nabi, A. (2011) Flow injection methods for the determination of $\alpha$-tocopherol with spectrophotometric detection. Journal of the Chemical Society of Pakistan, 4, 508-514.

[12] Shyla, B. and Nagendrappa, G. (2012) New spectrophotometric methods for the determinations of hydrogen sulfide present in the samples of lake water, industrial effluents, tender coconut, sugarcane juice and egg. Spectrochimica Acta, Part A: Molecular and Biomolecular Spectroscopy, 96, 776-783. http://dx.doi.org/10.1016/j.saa.2012.07.011

[13] Nakai, H., Teshima, N. and Sakai, T. (2010) Spectrophotometric flow injection analysis for formaldehyde in wastewater using hydroxylamine sulfate and iron(III)1,10-phenanthroline complex. Bunseki Kagaku, 59, 273278. http://dx.doi.org/10.2116/bunsekikagaku.59.273

[14] Katsumata, H., Sekine, T., Teshima, N., Kurihara, M. and Kawashima, T. (2000) A new flow-injection determination of glucose based on the redox reaction of hydroquinone with iron(III) in the presence of 1,10-phenanthroline. Talanta, 51, 1197-1204. http://dx.doi.org/10.1016/S0039-9140(00)00313-1

[15] Luque-Perez, E., Rios, A. and Valcarcel, M. (1998) Flowinjection spectrophotometric determination of citric acid in beverages based on a photochemical reaction. Analytica Chimica Acta, 366, 231-240. http://dx.doi.org/10.1016/S0003-2670(98)00110-X

[16] Lau, O.W., Luk, S.F. and Huang, H.L. (1989) Spectrophotometric determination of tannins in tea and beer samples with iron(111) and 1,10-phenanthroline as reagents. Analyst, 114, 631-633.

http://dx.doi.org/10.1039/an9891400631

[17] ANVISA (2010) Brazilian pharmacopoeia. 5th edition, ANVISA, Brasília, 355-357.

[18] Silva, D.X., Souza, M.W., Corrêa, C.S. and Moya, H.D. (2013) A critical study of use of the Fe(II)/3-hydroxy4-nitroso-2,7-naphthalenedisulfonic acid complexes in the quantification of polyphenols in medicinal plants. Food Chemistry, 138, 1325-1332. http://dx.doi.org/10.1016/j.foodchem.2012.11.045

[19] Rufino, M.S.M., Alves, R.E., Brito, E.S., Morais, S.M., Sampaio, C.G., Pérez-Jiménez, J. and Saura-Calixto, F.D. (2007) Metodologia científica: Determinação da atividade antioxidante totl em frutas pela captura do radical livre DPPH. Embrapa Agroindústria Tropical, 2007, 16796535.

[20] Sánchez-Moreno, C., Larrauri, J.A. and Saura-Calixto, F. (1998) A procedure to measure the antiradical efficiency of poplyphenols. Journal of the Science of Food and Agriculture, $\mathbf{7 6}, 270-276$ http://dx.doi.org/10.1002/(SICI)1097-0010(199802)76:2< 270::AID-JSFA945>3.0.CO;2-9

[21] Marino, D.C., Lacerda, L.Z.L., Armando Jr., J., Ruggiero, A.A. and Moya, H.D. (2009) Analysis of the polyphenols content in medicinal plants based on the reduction of $\mathrm{Cu}(\mathrm{II}) /$ bicinchoninic complexes. Journal of Agricultural and Food Chemistry, 57, 11061-11066. http://dx.doi.org/10.1021/jf902197p

[22] Jeffery, G.H., Bassett, J., Mendham, J. and Denney, R.C. (1989) Textbook of quantitative chemical analysis. 5th edition, Longman Group UK Limited, Essex, 142. 
[23] Nakamura, T., Coichev, N. and Moya, H.D. (2012) Modified CUPRAC spectrophotometric quantification of total polyphenol content in beer samples using $\mathrm{Cu}(\mathrm{II}) /$ neocuproine complexes. Journal of Food Composition and Analysis, 28, 126-134. http://dx.doi.org/10.1016/j.jfca.2012.07.012

[24] Lee, G., Rossi, M.V., Coichev, N. and Moya, H.D. (2011) The reduction of $\mathrm{Cu}(\mathrm{II}) /$ neocuproine complexes by some polyphenols. Analytical application in wine samples. Food Chemistry, 126, 679-686. http://dx.doi.org/10.1016/j.foodchem.2010.11.020

[25] Singleton, V.L., Orthofer, R. and Lamuela-Raventós, R. M. (1999) Analysis of total phenols and other oxidation substrates and antioxidants by means of Folin-Ciocalteu reagent. Methods in Enzymology, 299, 152-179. http://dx.doi.org/10.1016/S0076-6879(99)99017-1

[26] Teshima, N., Katsumata, H., Kurihara, M., Sakai, T. and Kawashima, T. (1999) Flow-injection determination of copper(II) based on its catalysis on the redox reaction of cysteine with iron(III) in the presence of 1,10-phenanthroline. Talanta, 50, 41-47.

http://dx.doi.org/10.1016/S0039-9140(99)00108-3

[27] Zhang, S.-F. (2008) Determination of polyphenols in tea by a new method spectrophotometry. Guangpuxue $Y u$ Guangpu Fenxi, 28, 1630-1632.

[28] Koch, S. and Peisker, S. (1990) Extraction-spectrophotometric determination of ascorbic acid with iron(III)/1,10phenanthroline. Zeitschrift fuer Chemie, 30, 184-185. http://dx.doi.org/10.1002/zfch.19900300519

[29] Patnaik, P. (2004) Section 4. In: Dean's Analytical Chemistry Handbook. 2nd edition, The McGraw-Hill Companies, New York, 71.

[30] Lorenzi, H. and Matos, F.J.A, (2002) Plantas medicinais no Brasil: Nativas e exóticas cultivadas, Instituto Plantarum, Nova Odessa.

\section{APPENDIX}

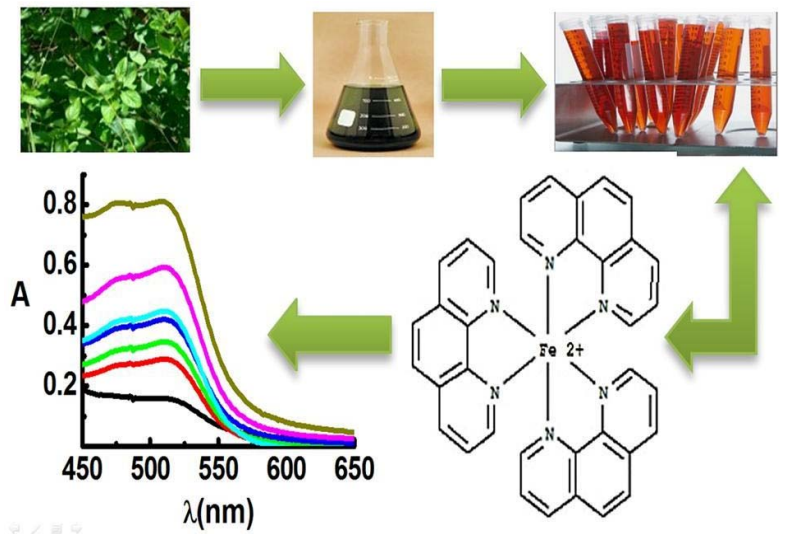

Figure Table of Contents. 